\author{
Lyudmila Melnyk ${ }^{1}$, Oleksandr Bessarab ${ }^{1}$, Svitlana Matko ${ }^{1}$ and \\ Myroslav Malovanyy²
}

\title{
ADSORPTION OF HEAVY METALS IONS FROM LIQUID MEDIA BY PALYGORSKITE
}

\author{
${ }^{1} \mathrm{~N}$ ational University of Food Technologies, 68, Volodymyrska str., 01601 Kyiv, Ukraine; plqaz@ukr.net \\ 2Lviv Polytechnic National University, 12, S. Bandery str., 79013 Lviv, Ukraine
}

Received: September 18, 2014 / Revised: September 27, 2014 / Accepted: J anuary 25, 2015

(C) Melnyk L., Bessarab O., Matko S., Malyovanyy M., 2015

\begin{abstract}
The process of heavy metals adsorption by natural mineral palygorskite from wastewater and food (apple juice) has been investigated. The purification processes of copper, cadmium, lead, mercury and zinc have been studied. The rational technological parameters of these processes have been determined. The mechanism for heavy metals adsorbtion from juice by palygorskite has been defined.
\end{abstract}

Keywords: adsorption, palygorskite, heavy metals, wastewater, apple juice.

\section{Introduction}

The problems of environment pollution by heavy metals became more urgent with the development of human activity and the spread of pollution in the hydrosphere and lithosphere.

The purification of wastewater with the aim of prevention of the hydrosphere contamination by heavy metals is very important. It is even more important to clean drinking water and food, because in case of of these products consumption a direct threat to human health is created. This report is dedicated to investigation of heavy metals removal from wastewater and contaminated fruit juice.

Contaminated with heavy metals wastewater is formed as a result of human activities. While getting into the environment, it causes pollution of the hydrosphere and soil, and getting into drinking water and food is transferred further to animals and humans. Existing methods of heavy metals removal from wastewater do not provide the required degree of purification; therefore we investigated the possibility to treat such wastewater with natural sorbents, including palygorskite.

In this regard, important challenge faced by the food industry is to provide the population with highquality products and ecologically safe beverages that meet the state standards of Ukraine.
Fruit and berry juices, including apple juice, are source of vitamins $\left(\mathrm{C}, \mathrm{D}, \mathrm{E}, \mathrm{B}_{6}, \mathrm{~B}_{2}, \mathrm{~B}_{1}, \mathrm{PP}\right.$, carotene, folic and pantothenic acids), pectin substances, valuable microelements, salts of potassium, calcium, copper, iron, magnesium sodium and organic acids [1, 2]. However, impurities harmful for health of the population, including heavy metal ions, could be found in the contents of this product.

Nowadays for the purpose of demetallization the canning industry applies chemical methods using silicon dioxide, potassium ferrocyanide (PF), citric acid and disodium dihydrogen ethylenediaminetetraacetate (Trilon B), which have several disadvantages, including: toxic reagents, multi-stage treatment, the probability of repeated feculence, changes in juice $\mathrm{pH}$ during process of its purification. The application of chemical methods to remove heavy metals from apple juice is undesirable, especially in the production of juices for infant nutrition [3, 4].

With the building of settlements, the problem of treatment of domestic and industrial effluents from the pollutants requires finding and implementing new effective solutions. One of these solutions is the use for sewage treatment of disperse natural sorbents (zeolites, bentonit, palygorskite, glauconit), which stocks a large number of mineral resources in the bowels of Ukraine. This report presents data about using palygorskite as a sorbent.

The pressing problem for modern manufacture of fruit and berry juices is to search the effective methods and reagents to remove these heavy metal ions, which would simultaneously provide both high stability and quality of the finished product.

In the authors' opinion, one of the most effective ways to improve the ecological safety of apple juice is additional adsorptive purification of semi-finished juice from heavy metal ions. For this purpose the authors have used palygorskite from the Cherkassy deposit as an adsorbent, which has layered and banded structure and 
belongs to minerals with rigid crystal grid. Previous studies proved its environmental safety and high adsorption properties with regard to pectin substances and harmful microorganisms [5, 6]. Palygorskite has high specific surface area, which defines large aggregate stability and adhesion ability with respect to juice that in turn prevents repeated feculence of the finished beverage and deterioration of its quality.

\section{Experimental}

In this study the palygorskite of the Dashava deposit (Cherkasy region) was used.

\subsection{W astewater Treatment}

We studied the effectiveness of wastewater treatment from the ions of lead, cadmium and copper. The mineral was sieved and the fraction with particles size of $1.5-2 \mathrm{~mm}$ was selected. The concentration of palygorskite in the synthetic wastewater was $5 \mathrm{wt} \%$. The initial concentration of metals in synthetic sewage was selected in such way that after obtaining the equilibrium concentrations the isotherms could be built correctly. The experiments were carried out in a stirred reactor, thermostated at $298 \mathrm{~K}$, with a contact time that allowed reaching the equilibrium state. The concentration of metals was determined by the methods of solid-phase spectrophotometry (SPS) [10] and atomic absorption spectroscopy (AAS ) [11].

\subsection{Apple J uice Treatment}

The apple juice was treated by palygorskite (the fraction of $3.0-2.0 \mathrm{~mm}$ ) which was thermoactivated at $453-463 \mathrm{~K}$ for $1.5 \mathrm{~h}$. Palygorskite in amount of 2-5 wt \% was added to the apple juice heated to $333-343 \mathrm{~K}$ under constant stirring for 20-40 min. The presented technological parameters were determined as the best ones on the basis of previous studies [9]. The resulting mixture was filtered and contents of $\mathrm{Cu}(\mathrm{II}), \mathrm{Pb}(\mathrm{II}), \mathrm{Cd}(\mathrm{II}), \mathrm{Zn}(\mathrm{II})$ and $\mathrm{Hg}(\mathrm{II})$ were determined in the filtrate by the methods of solid-phase spectrophotometry (SPS) [10] and atomic absorption spectroscopy (AAS ) [11] with the help of S-115-M1 device. Discrepancy between the results obtained the two methods was $2-5 \%$, that demonstrates high precision of each method.

\section{Results and Discussion}

\subsection{W astewater Treatment}

Fig. 1 shows sorption isotherms of $\mathrm{Pb}^{2+}, \mathrm{Cd}^{2+}$ and $\mathrm{Cu}^{2+}$ ions from the solutions with the same initial concentration.

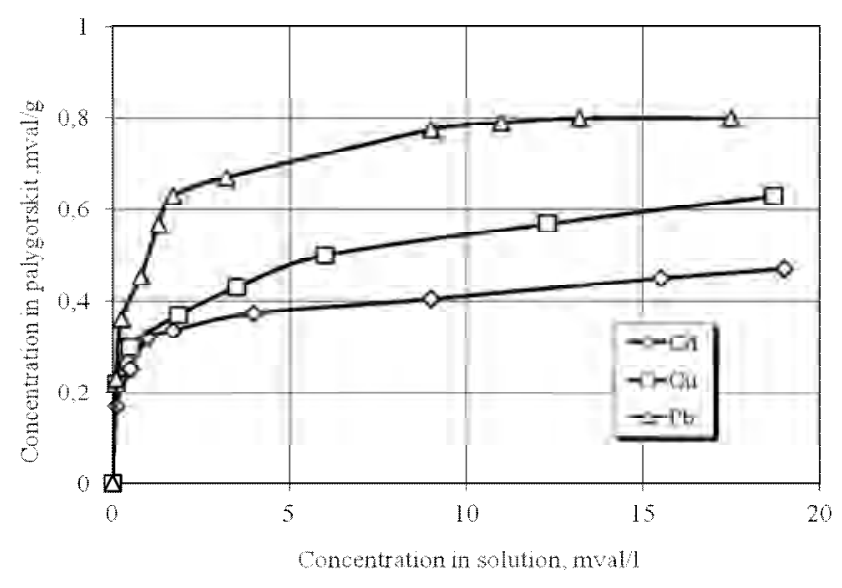

Fig. 1. Isotherms of copper, cadmium and lead ions adsorption by paligorskite at $298 \mathrm{~K}$

The position of the curves shows the highest cleaning efficiency of solutions from $\mathrm{Pb}^{2+}$ ion, then $\mathrm{Cd}^{2+}$ ion, and the least efficiency - from $\mathrm{Cu}^{2+}$ ion. The received experimental data are in a good agreement with the data of other researchers $[7,8]$. Based on these studies, we can assert that the selectivity row concerning the removal of the studied cations from the solutions using palygorskite has the form of $\mathrm{Pb}(\mathrm{II})>\mathrm{Cu}$ (II) $>\mathrm{Cd}$ (II).

\subsection{Apple J uice Treatment}

The content of heavy metals in the control sample (untreated apple juice):

$\mathrm{Cu}(\mathrm{II})=4.5 \mathrm{mg} / \mathrm{dm}^{3} \quad($ Maximum Permissible Concentrations, $\mathrm{MPC}=5.0 \mathrm{mg} / \mathrm{dm}^{3}$ )

$$
\begin{aligned}
& \mathrm{Pb}(\mathrm{II})=0.52 \mathrm{mg} / \mathrm{dm}^{3}\left(\mathrm{MPC}=0.3 \mathrm{mg} / \mathrm{dm}^{3}\right) \\
& \mathrm{Cd}(\mathrm{II})=0.04 \mathrm{mg} / \mathrm{dm}^{3}\left(\text { MPC }=0.02 \mathrm{mg} / \mathrm{dm}^{3}\right) \\
& \mathrm{Zn}(\mathrm{II})=14.7 \mathrm{mg} / \mathrm{dm}^{3}\left(\text { MPC }=10.0 \mathrm{mg} / \mathrm{dm}^{3}\right) \\
& \mathrm{Hg}(\mathrm{II})=0.038 \mathrm{mg} / \mathrm{dm}^{3}\left(\text { MPC }=0.01 \mathrm{mg} / \mathrm{dm}^{3}\right) .
\end{aligned}
$$

Adsorption capacity of the natural minerals with regard to adsorbing heavy metals from the apple juice has been estimated by the purification effect, calculated according to the formula:

$$
E=\frac{100 \cdot\left(K_{1}-K_{2}\right)}{K_{1}}
$$

where $K_{1}$ and $K_{2}$ - quantities of the polluter in untreated juice and the juice treated by the adsorbent, respectively.

The obtained results are represented in Figs. 2-6.

It follows from Fig. 2 that the effect of apple juice purification from copper in the experimental samples is growing rapidly during the first $20 \mathrm{~min}$ and stays within the range of $26-34 \%$ with all concentrations of the adsorbent. During the juice treatment the copper removal still continues for the next $10 \mathrm{~min}$, but then slows down.

The highest effect of juice purification from copper ions is observed in the samples with the concentration of 
the adsorbent being $5.0 \mathrm{wt} \%$ and constitutes $37.8 \%$ with a duration of processing attaining $30 \mathrm{~min}$.

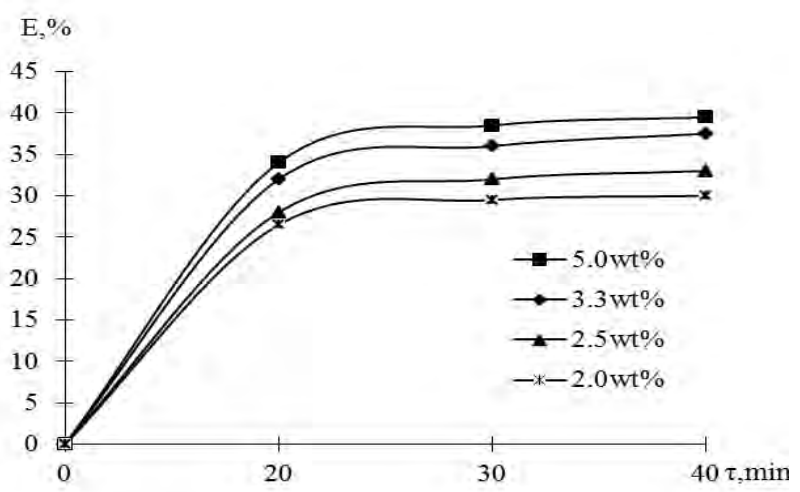

Fig. 2. Effect of apple juice purification from copper ions by palygorskite

The nature of curves which describe the removal of cadmium ions from the apple juice (Fig. 3) varies depending on the duration of treatment. During the first $20 \mathrm{~min}$ the content of cadmium ions is reduced by $39-50 \%$, depending on the palygorskite concentration. This tendency of decrease in harmful impurities content also remains when the duration of treatment is increased, reaching the maximum level of purification effect $61-62 \%$ (for the adsorbent concentration of 3.3 and $5.0 \mathrm{wt} \%$, with the treatment duration of $30 \mathrm{~min}$ ). Further interaction between the adsorbent and apple juice is not feasible. Taking into account that the obtained results of the purification effect are almost identical while the concentration of the adsorbent in juice:palygorskite mixture is different, it is feasible to recommend commercial introduction of the adsorbent content being $3.3 \mathrm{wt} \%$.

Analyzing data from Fig. 4, it is possible to state that adsorption of zinc ions from the apple juice is more effective when the palygorskite concentration is $5.0 \mathrm{wt} \%$ and treatment duration is $30-40 \mathrm{~min}$. Effect of juice purification constitutes 36-38\%.

It follows from Fig. 5 that mercury ions are better adsorbed from the apple juice when adsorbent concentration in the mixture is $3.3-5.0 \mathrm{wt} \%$ with treatment duration of $30 \mathrm{~min}$, thus attaining the effect of purification at the level of $73-75 \%$. To save palygorskite, it is feasible to recommend commercial introduction of palygorskite with the concentration of $3.3 \mathrm{wt} \%$ and treatment duration of $30 \mathrm{~min}$. When using palygorskite with the concentration of 2.0 and $2.5 \mathrm{wt} \%$ during $40 \mathrm{~min}$ of interaction the effect of purification from mercury ions attains only $38-40 \%$.

The outcomes of the research, presented in Fig.6, give grounds for conclusion that with duration of interaction between the juice and the adsorbent being $30 \mathrm{~min}$ the effect of apple juice purification by palygorskite from lead ions is the following: $35.5 \%$ (with the adsorbent content of $5.0 \mathrm{wt} \%$ ); $34.5 \%$ (with palygorskite concentration of $3.3 \mathrm{wt} \%) ; 32.5$ and $30.5 \%$ (when the adsorbent content in the mixture is 2.5 and $2.0 \mathrm{wt} \%$, respectively).

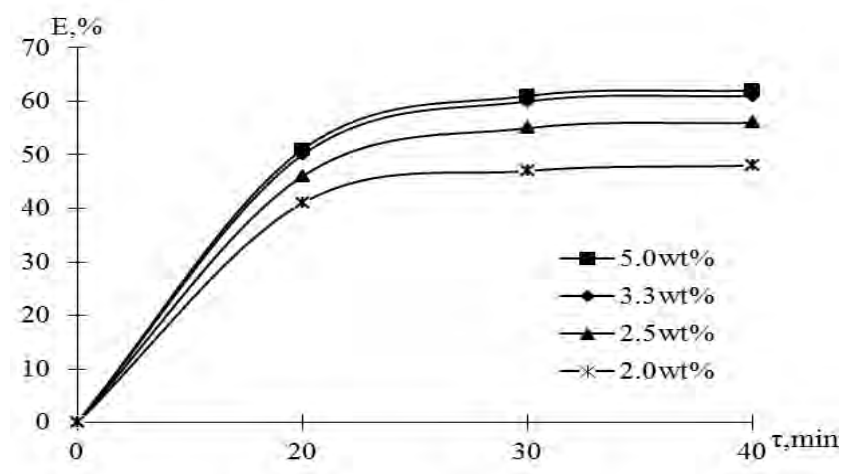

Fig. 3. Effect of apple juice purification from cadmium ions by palygorskite

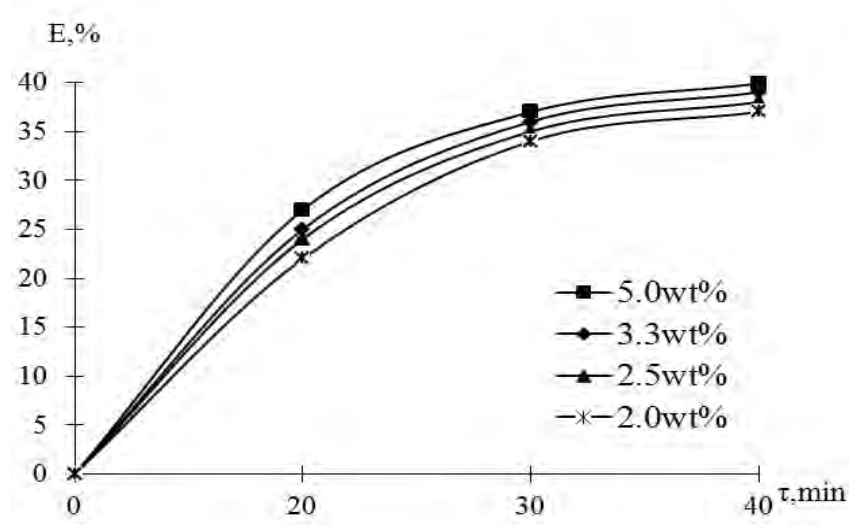

Fig. 4. Effect of apple juice purification from zinc ions by palygorskite

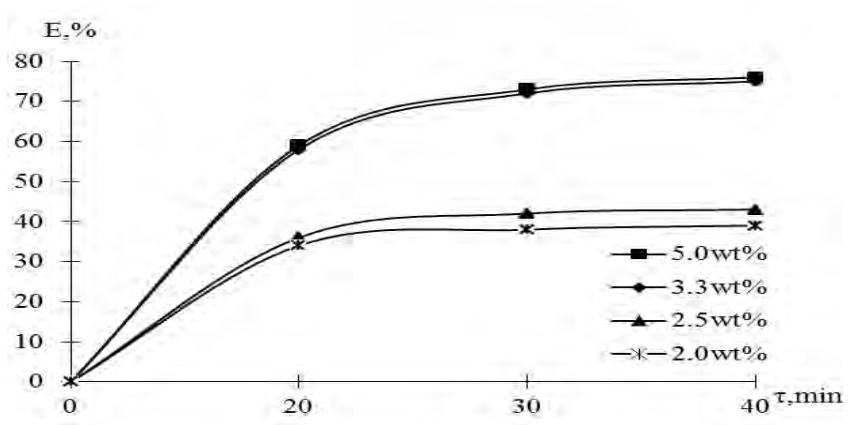

Fig. 5. Effect of apple juice purification from mercury ions by palygorskite 
The mechanism of heavy metal ions adsorption can be explained by the structure of palygorskite surface which contains active centers due to nonstoichiometric isomorphism and broken links of $\mathrm{O}-\mathrm{Si}-\mathrm{O}$ at the edges and ends of the crystals. The number of these centers during mechanical dispersion of palygorskite under humid condition sharply increases as a result of large number of chips and defects on the surface. Edges of palygorskite crystals are saturated by homogeneous $\mathrm{OH}$-groups and that increases its total surface energy.

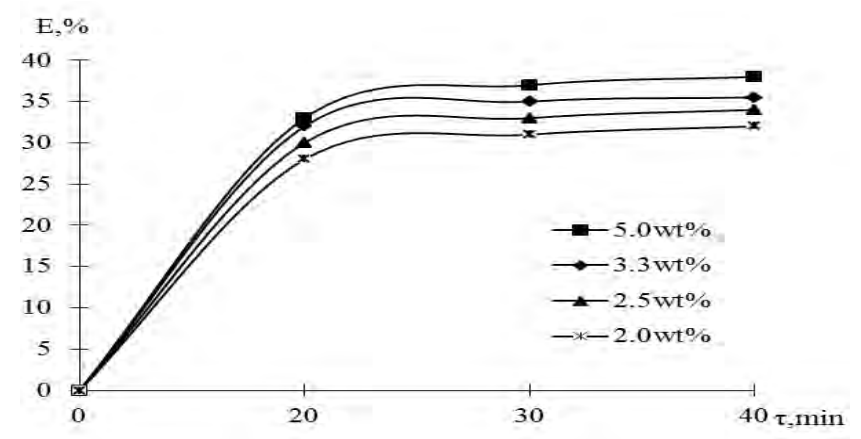

Fig. 6. Effect of apple juice purification from lead ions by palygorskite

\section{Conclusions}

The nature of adsorption isotherms in the case of wastewater treatment by palygorskite from ions of copper, lead and cadmium was found.

The efficiency of adsorption purification of the apple juice from the heavy metals ions with the help of palygorskite has been proved. It has been determined that the selectivity row concerning the removal of the studied cations from the solutions with the use of palygorskitee has the form of $\mathrm{Pb}$ (II) $>\mathrm{Cu}$ (II) $>\mathrm{Cd}$ (II).

As the result of the research the authors have established the following effect of apple juice purification by palygorskite: from copper ions $27-38 \%$; cadmium $46-$ $62 \%$; lead 30-36\%; mercury $73-75 \%$ and zinc $36-38 \%$.

To improve ecological safety of the juice it should be recommended to introduce the following rational technological parameters of apple juice treatment by palygorskite into the industry: sorbent concentration in the juice:palygorskite mixture is $3.3 \mathrm{wt} \%$ with the duration of interaction constituting $30 \mathrm{~min}$.

\section{References}

[1] Savona N.: Bolshaya Kniga Sokov. Fair-Press, Moskwa 2008.

[2] Genovese D. and Lozano J.: J. Food Sci., 2000, 4, 641.

[3] Kiseleva T.: Technologiya Konservirovaniya. Prospect Nauki, Sankt-Peterburg 2011.

[4] Sheiko T. and Melnik L.:The Annual World Conf. on Carbon, USA, Clemson 2010, 16.

[5] Palygorskite dlya Vynorobnoi Promyslovosti [in:] Dergavni Standarty Ukrainy. Kyiv 1996, 13.

[6] Mank V. and Melnyk L.: XVII Int. Conf. on Clay Mineralogy and Petrology, Prague 2004, 43.

[7] Veli S. and Alyuz B.: J. Hazardous Mat., 2007, 149, 226.

[8] Choy J., Choy S. and Park T.: Appl. Clay Sci., 2007, 36, 122.

[9] Matko S., Mank V., Zhestereva N.and Melnyk L: IV Mezdunar. Conf. Studentov i Aspirantov "Technika I Technologiya Pishchevoi Promyshlennosti”, Belarus, Mogilev 2004, 182.

[10] Kostenko E. and Shtokalo M.: Zh. Anal. Khim., 2004, 59, 1276.

[11] EN 14627:2005. Foodstuffs. Determination of trace elements by hydride generation atomic absorption spectrometry (HGAAS).

\section{АДСОРБЦІЯ ЙОНІВ ВАЖКИХ МЕТАЛІВ ІЗ РІДИННИХ СЕРЕДОВИЩ ПАЛИГОРСЬКІТОМ}

Анотація. Досліджено процес адсорбиії важких металів природним мінералом палигорськітом із стічних вод та харчових продуктів (яблучного соку). Досліджені прочеси очищчення від йонів міді, кадмію, свинцю, ртуті, ичику та визначено раціональні технологічні параметри цьього прочесу. Встановлено механізм сорбиії важких металів із соку палигорськітом.

Ключові слова: адсорбиія, палигорськіт, важкі метали, стічні води, яблучний сік. 